\title{
Pengaruh Return On Equity, Rasio Operasi, Dan Cash Ratio Terhadap Tingkat Kesehatan Keuangan Yang Dimoderasi Oleh Penyertaan Modal dan Efektivitas Penagihan (Studi pada PDAM Bantul Tahun 2009-2019)
}

\author{
Arinto Hendro Budiantoro ${ }^{1}$, Sri Hermuningsih ${ }^{2}$, Gendro Wiyono ${ }^{3}$ \\ ${ }^{1)}$ Program Studi Magister Manajemen, Fakultas Ekonomi, Universitas Sarjana \\ Wiyata Tamansiswa
}

\begin{abstract}
The finacial health of a company pertains its effort to mantain its survivability and industrial activities as well as measuring how far as a business entity can ensure its sound operation. The level of a company's finacial health can be known by measuring its finacial performance. In this research financial health is studied with its correlation with Return On Equity, Operating Ratio, Cash Ratio, Equity Participation, and Colection Effectiveness. Return On Equity (ROA) measures the effectiveness of a company in maximizing its assets. Operating Ratio in this study relies on Net Profit Margin (NPM). This indicates how far the percentage of net income coming from each sale. Cash ratio is a measurement of minimum liquidity that a company must maintain. Equity Participation in this research refers to investment capital provided by the government either as equity or in the form of direct investment. Collection effectiveness describes the ratio between results from collection attempts relative to specified target.
\end{abstract}

\section{Keywords: company, finance, operating ratio}

\section{PENDAHULUAN}

Tingkat kesehatan perusahaan adalah mempertahankan kelangsungan hidup dan kelancaran proses industrinya serta menjadi tolak ukur untuk memantau sejauh mana perusahaan mampu menjaga agar kelancaran operasi perusahaan tidak terganggu. Tingkat kesehatan perusahaan dapat diketahui dengan menilai kinerja keuangan perusahaan tersebut. Menurut Yuwono (2010), penilaian kinerja tersebut dapat dilakukan dengan menggunakan rasio keuangan. Hasil pengukuran berdasarkan rasio tersebut diterapkan untuk menentukan tingkat kesehatan perusahaan yang dikategorikan sebagai berikut: sehat, cukup sehat, kurang sehat dan tidak sehat.

Mempertahankan kelancaran proses sebuah perusahaan perlu menganalisis dan menginterpretasikan laporan keuangannya. Laporan keuangan merupakan alat yang sangat penting untuk mengetahui informasi, sehubungan dengan kondisi keuangan dan hasil-hasil yang dicapai oleh perusahaan.

Perusahaan Daerah Air Minum (PDAM) merupakan perusahaan yang berorientasikan sosial. Sesuai dengan keputusan Menteri Dalam Negeri No: 690069 tahun 1992 tentang petunjuk teknis pengelolaan PDAM ditegaskan bahwa PDAM mempunyai tugas pokok pelayanan umum pada masyarakat. Perusahaan PDAM Tirta Dharma Kabupaten Bantul merupakan Badan Usaha Milik Daerah (BUMD) yang didirikan berdasarkan Perda Kabupaten Dati II Bantul No 11 
Tahun 1990 yang diundangkan melalui Lembaran Daerah Kabupaten Dati II Bantul No-8 Tahun 1991 seri D tanggal 22 April 1991. Cara untuk mengetahui keberhasilan perusahaan PDAM dalam mencapai tujuan dapat dengan mengevaluasi kinerja yang terdiri dari 4 (empat) yaitu : aspek keuangan, aspek pelayanan, aspek operasional, dan aspek sumber daya manusia. Untuk aspek keuangan dapat diukur dengan angka-angka yang terdapat dilaporan keuangan yang disusun secara periode yang berupa neraca, laporan laba/rugi, dan laporan arus kas.

Kesehatan keuangan dalam penelitian ini akan dipengaruhi oleh Return On Equity, Rasio Operasi, Cash Ratio, Penyertaan Modal, dan Efektivitas Penagihan. Return On Equity (ROA) mencoba mengukur efektifitas perusahaan dalam memanfaatkan seluruh aktiva. Rasio Operasi dalam penelitian ini menggunakan Net Profit Margin (NPM). Rasio ini menunjukkan berapa besar presentase pendapatan bersih yang diperoleh dari setiap penjualan. Cash ratio adalah alat pengukuran likuiditas minimum yang wajib dipelihara oleh setiap perusahaan.

Penyertaan modal dalam penelitian ini merupakan penyertaan modal investasi yang dilakukan oleh pemerintah dalam bentuk/jenis investasi surat berharga dan investasi langsung. Efektivitas penagihan merupakan perbandingan antara hasil penagihan dengan tujuan atau target yang telah ditetapkan. Formula untuk mengukur efektivitas yang terkait dengan penagihan adalah perbandingan antara realisasi hasil penagihan dengan target penagihan.

\section{TINJAUAN PUSTAKA}

\section{Kesehatan Keuangan}

Kesehatan keuangan adalah hasil penilaian kondisi perusahaan pembiayaan terhadap risiko permodalan, likuiditas, aset, operasional dan kinerja perusahaan pembiayaan. Tingkat kesehatan keuangan perusahaan perusahaan diperlukan untuk melihat apakah suatu keuangan dalam suatu perusahaan itu dalam keadaan sehat atau tidak.

\section{Return On Equity (ROA)}

Return On Equity adalah rasio yang digunakan mengukur kemampuan perusahaan menghasilkan keuntungan secara relatif dibandingkan dengan total modalnya atau ukuran untuk menilai seberapa besar tingkat pengembalian dari modal perusahaan (Santoso, 2010). Rasio ini sangat penting, mengingat keuntungan yang memadai diperlukan untuk mempertahankan arus sumbersumber modal perusahaan.

\section{Rasio Operasi}

Rasio operasi merupakan rasio yang dapat mengukur tingkat efisiensi perusahaan yang disebabkan oleh besarnya biaya operasi dalam setiap penjualan aktivanya. Rasio operasi digunakan untuk mengevaluasi margin laba dari ativitas operasi. Rasio operasi dihitung dari penjualan dibagi dengan total biaya. Rasio juga merupakan gabungan pendapatan bersih dikurangi dengan pendapatan investasi bersih yang diperoleh. Rasio operasi lebih dari 100 menunjukkan 
perusahaan tidak dapat menghasilkan keuntungan dari penjaminan dan kegiatan investasi.

\section{Cash Ratio}

Cash ratio adalah alat pengukuran likuiditas minimum yang wajib dipelihara oleh setiap perusahaan. Cash ratio merupakan perbandingan antara alat-alat likuid yang dikuasai perusahaan dengan kewajiban yang harus segera dibayar. Rasio ini paling akurat dalam mengukur kemampuan perusahaan untuk memenuhi kewajiban jangka pendek karena hanya memperhitungkan komponen aktiva lancar yang paling likuid.

\section{Penyetaraan Modal}

Menurut Balfas (2010) modal merupakan efek yang paling umum ditawarkan dalam suatu penawaran umum, merupakan instrumen yang paling umum dikenal dan diperdagangkan di pasar modal. Saham merupakan komponen dan wujud dari penyertaan modal dalam suatu usaha berbentuk perseroan terbatas. Penyertaan modal yang dilakukan juga berdasarkan oleh ketentuan-ketentuan umum yang ada mengenai penanaman saham.

\section{Efektivitas Penagihan}

Menurut Mahmudi (2010) efektivitas adalah hubungan antara output dengan tujuan, semakin besar kontribusi / sumbangan output terhadap pencapaian tujuan, maka semakin efektif organisasi, program atau kegiatan. Efektivitas penagihan digunakan untuk mengukur hubungan antara hasil penagihan dengan tujuan atau target yang telah ditetapkan. Rumus untuk mengukur efektivitas penagihan sebagai berikut,

Efektivita s Penagihan $=\frac{\text { Rekening Tertagih }}{\text { Penjualan Air }} \times 100 \%$

\section{METODE PENELITIAN}

\section{Subjek dan Objek Penelitian}

Subjek penelitian ini adalah perusahaan PDAM Bantul, sedangkan objek penelitian ini adalah Return On Equity, Rasio Operasi, dan Cash Ratio, Rasio Kesehatan Keuangan, Penyertaan Modal, dan Efektivitas Penagihan dari tahun 2009-2019.

\section{Jenis dan Sumber Data}

Jenis data yang digunakan dalam penelitian ini adalah data sekunder. Sumber data yang digunakan dalam penelitian ini berasal dari laporan keuangan perusahaan PDAM Bantul di website https://www.pdambantul.com/.

\section{Metode Analisis Data}

Analisis data penelitian menggunakan metode analisis regresi linier berganda model moderating regression analysis (MRA), dengan paket program IBM SPSS Statistics, kemudian dilakukan interpretasi faktor-faktor yang mempengaruhi tingkat kesehatan keuangan. 


\section{a. Analisis Deskriptif}

Analisis deskriptif dalam penelitian ini menggambarkan / mendiskripsikan nilai mean, minimum, maximum, dan standart deviation masing-masing variabel penelitian.

b. Analisis Regresi Linier Berganda Model Moderating Regression Analysis Regresi Linier Berganda Model Moderating Regression Analysis dalam penelitian ini digunakan untuk mengetahui adanya pengaruh variabel independen terhadap variabel dependen secara parsial maupun simultan. Adapun persamaan regresi yang dikembangkan dalam penelitian ini adalah sebagai berikut:

$Y=\alpha+\beta_{1} X_{1}+\beta_{2} X_{2}+\beta_{3} X_{3}+e$ untuk hipotesis prediktor tanpa moderasi.

$\mathrm{Y}=\alpha+\beta_{1} \mathrm{X}_{1}+\beta_{2} \mathrm{X}_{2}+\beta_{3} \mathrm{X}_{3}+\beta_{4} \mathrm{X}_{1} * \mathrm{Z}_{1}+\beta_{5} \mathrm{X}_{1} * \mathrm{Z}_{2}+\beta_{6} \mathrm{X}_{2} * \mathrm{Z}_{1}+\beta_{7} \mathrm{X}_{2} * \mathrm{Z}_{2}+$ $\beta_{8} X_{3} * Z_{1}+\beta_{9} X_{3} * Z_{2}+$ e untuk hipotesis prediktor dengan moderasi

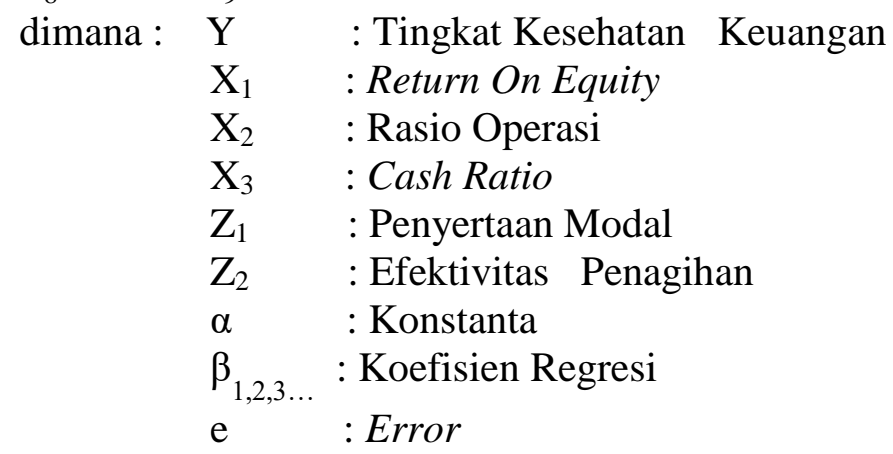

\section{c. Uji Asumsi Klasik}

1. Uji Normalitas

Uji normalitas bertujuan untuk menguji apakah dalam model regresi variabel dependen dan variabel independen mempunyai distribusi normal atau tidak. Model regresi yang baik adalah memiliki distribusi data normal atau mendekati normal (Ghozali, 2016). Untuk menguji normalitas, dapat menganalisis nilai Kolmogorov Smirnov Test. Dasar pengambilan keputusan adalah jika nilai probabilitas $>0,05$, maka model regresi memenuhi asumsi normalitas, maka model regresi memenuhi asumsi normalitas dan sebaliknya.

\section{Uji Multikolinearitas}

Uji multikolinearitas bertujuan untuk menguji apakah dalam model regresi ditemukan adanya korelasi antar variabel independen. Model regresi yang baik seharusnya tidak terjadi korelasi di antara variabel independen. Upaya untuk mendeteksi ada atau tidaknya multikolinearitas di dalam suatu model regresi dapat dilakukan dengan melihat nilai Variance Inflation Factor (VIF). VIF menunjukkan setiap variabel independen manakah yang dijelaskan oleh variabel independen lainnya. nilai VIF lebih besar dari 10, maka terjadi multikolinearitas (Ghozali, 2016). 


\section{Autokorelasi}

Autokorelasi bertujuan untuk menguji apakah dalam model regresi linier ada korelasi antara residual periode $\mathrm{t}$ dengan residual pada periode $\mathrm{t}-1$ (periode sebelumnya). Jika terjadi korelasi, maka ada masalah autokorelasi. Autokorelasi terjadi karena observasi yang berurutan sepanjang waktu berkaitan satu sama lain (Ghozali, 2016). Untuk melihat adanya autokorelasi digunakan Durbin Watson Test (DW). Dari tabel nilai DW akan didapatkan nilai kritis dU dan dL.

- Jika d $<\mathrm{dL}$ atau $(4-\mathrm{dL})<\mathrm{d}$, maka terdapat autokorelasi didalam model regresi.

- Jika $\mathrm{dL} \leq \mathrm{d} \leq \mathrm{dU}$ atau $(4-\mathrm{dU}) \leq \mathrm{d} \leq(4-\mathrm{dL})$, maka pengujian tidak meyakinkan.

- Jika $2<\mathrm{d}<(4-\mathrm{dU})$ atau $\mathrm{dU}<\mathrm{d}<2$, maka tidak terdapat autokorelasi di dalam model regresi.

\section{Uji Heterokedastisitas}

Uji Heteroskedastisitas bertujuan untuk menguji apakah dalam model regresi terjadi ketidaksamaan varian dari residual atau observasi ke observasi yang lain. Jika varian residual satu observasi ke observasi lain tetap, maka disebut homoskedastisitas dan jika berbeda disebut heterskedastisitas. Model regresi yang baik adalah homoskedastisitas (Ghozali, 2016). Uji Heterokedastisitas dilakukan dengan uji Glejser, yaitu dengan meregresikan nilai absolute residual dengan variabel independennya. Ada tidaknya heteroskedastisitas dapat diketahui dengan melihat tingkat signifikansinya terhadap alpha $(\alpha)$ $5 \%$. Jika nilai signifikansinya lebih besar dari alpha $(\alpha)$, maka tidak terjadi heteroskedastisitas.

\section{d. Uji Statistik}

\section{Uji t (t-test)}

Uji t digunakan untuk membuktikan pengaruh variabel independen terhadap variabel dependen secara individual dengan asumsi bahwa variabel yang lain tetap atau konstan. Hipotesis pengujiannya sebagai berikut,

$\mathrm{Ha}: \beta \mathrm{i}=0$ (Variabel independen tidak berpengaruh signifikan terhadap variabel dependen)

Kriteria uji :

- Bila probabilitas $\mathbf{t}_{\text {-statistik }}>$ Level of Significant $=0,05$, maka $\mathrm{Ha}$ ditolak.

- Bila probabilitas $\mathbf{t}_{\text {-statistik }}<$ Level of Significant $=0,05$, maka Ha diterima.

\section{Pengujian Goodness of Fit}

Pengujian Goodness of Fit menggunakan $\mathrm{R}^{2}$ (Koefisien Determinasi) untuk mengetahui seberapa besar kemampuan variabel independen dalam menjelaskan variabel dependen. Nilai $R^{2}$ (Koefisien Determinasi) mempunyai range antara 0-1. Semakin besar $\mathrm{R}^{2}$ mengindikasikan semakin besar 
kemampuan variabel independen dalam menjelaskan variabel independen (Gujarati \& Dawn, 2012).

\section{HASIL DAN PEMBAHASAN}

a. Analisis Deskriptif

Tabel 1.

Statistik Deskriptif Variabel Penelitian

\begin{tabular}{lcccc}
\hline \multicolumn{1}{c}{ Variabel } & Min & Max & Mean & SD \\
\hline Tingkat Kesehatan & 2 & 3 & 2,91 & $\mathbf{0 , 3 0 2}$ \\
Keuangan $(Y)$ & & & & \\
Return On Equity $\left(\mathbf{X}_{\mathbf{1}}\right)$ & 0,68 & 27,79 & 6,3655 & $\mathbf{9 , 3 7 2 5 4}$ \\
Rasio Operasi $\left(\mathbf{X}_{\mathbf{2}}\right)$ & 0,44 & 1,15 & 0,8864 & $\mathbf{0 , 2 2 2 9 5}$ \\
Cash Ratio $\left(\mathbf{X}_{\mathbf{3}}\right)$ & 63,82 & 282,79 & 130,0973 & $\mathbf{7 9 , 4 6 0 2}$ \\
Penyertaan Modal $\left(\mathbf{Z}_{\mathbf{1}}\right)$ & 18,81 & 22,63 & 21,3536 & $\mathbf{1 , 3 2 8 1 6}$ \\
\hline Efektivitas Penagihan $\left(\mathbf{Z}_{\mathbf{2}}\right)$ & $\mathbf{9 5 , 5 0}$ & $\mathbf{1 0 0 , 4 1}$ & $\mathbf{9 6 , 9 9 5 5}$ & $\mathbf{1 , 4 4 5 0 9}$ \\
\hline
\end{tabular}

\section{Sumber: Hasil Olah Data Statistik Deskriptif, 2020.}

Berdasarkan Tabel 1 di atas, dapat dijelaskan beberapa hal berikut:

- Mean Rata-rata Tingkat Kesehatan Keuangan (Y) sebesar 2,91, nilai minimum sebesar 2, nilai maksimum sebesar 3, dan standar deviasi sebesar 0,302 .

- Rata-rata Return On Equity (X1) sebesar 6,3655 (efisien), nilai minimum sebesar 0,68, nilai maksimum sebesar 27,79, dan standar deviasi sebesar 9,37254 .

- Rata-rata Rasio Operasi (X2) sebesar 0,8864 (efisien), nilai minimum sebesar 0,44 , nilai maksimum sebesar 1,15, dan standar deviasi sebesar 0,22295.

- Rata-rata Cash Ratio (X3) sebesar 130,0973 (baik), nilai minimum sebesar 63,82, nilai maksimum sebesar 282,79, dan standar deviasi sebesar 79,4602.

- Rata-rata Penyertaan Modal ( $\left.Z_{1}\right)$ sebesar 21,3536 (cukup), nilai minimum sebesar 18,81, nilai maksimum sebesar 22,63, dan standar deviasi sebesar 1,32816 .

\section{b. Analisis Regresi Linier Berganda}

Analisis ini digunakan untuk mengetahui pengaruh dari variabel Return On Equity (X1), Rasio Operasi (X2), dan Cash Ratio (X3) terhadap Tingkat Kesehatan Keuangan (Y). Berdasarkan hasil perhitungan dengan menggunakan program statistik komputer SPSS for Windows diperoleh hasil sebagai berikut: 
Tabel 2.

Hasil Regresi Linier Berganda

\begin{tabular}{|c|c|c|c|c|}
\hline Var & Koef & SE & t-test & Sig. \\
\hline $\bar{C}$ & 4,225 & 0,341 & 12,402 & 0,000 \\
\hline $\mathbf{X}_{1}$ & 0,033 & 0,007 & 4,707 & $\mathbf{0 , 0 0 2}$ \\
\hline $\mathbf{X}_{2}$ & 1,284 & 0,316 & 4,065 & 0,005 \\
\hline $\mathbf{X}_{3}$ & 0,002 & 0,001 & 2,537 & $\mathbf{0 , 0 3 9}$ \\
\hline $\mathbf{R}^{2}$ & \multicolumn{4}{|c|}{ : 0,885} \\
\hline Adj. $R^{2}$ & \multicolumn{4}{|c|}{ : $\mathbf{0 , 8 3 6}$} \\
\hline $\mathbf{F}$-statistik & \multicolumn{4}{|c|}{ : 17,931, Sig = 0,000. } \\
\hline DW-statistik & \multicolumn{4}{|c|}{ : 2,141} \\
\hline $\mathbf{N}$ & \multicolumn{4}{|l|}{$: 11$} \\
\hline
\end{tabular}

Sumber: Hasil Olah Data Regresi Linier Berganda, 2020.

Secara matematis hasil dari analisis regresi linier berganda tersebut dapat ditulis sebagai berikut:

$\mathrm{Y}=4,225+0,033 \mathrm{X}_{1}+1,284 \mathrm{X}_{2}+0,002 \mathrm{X}_{3}$

c. Analisis Regresi Linier Berganda Model Moderating Regression Analysis Analisis ini digunakan untuk mengetahui apakah Penyertaan Modal (Z1) memoderasi pengaruh Return On Equity (X1), Rasio Operasi (X2), dan Cash Ratio (X3) terhadap Tingkat Kesehatan Keuangan pada perusahaan PDAM Bantul Tahun 2009-2019 dan apakah Efektivitas Penagihan (Z2) memoderasi pengaruh Return On Equity (X1), Rasio Operasi (X2), dan Cash Ratio (X3) terhadap Tingkat Kesehatan Keuangan pada perusahaan PDAM Bantul Tahun 2009-2019. Berdasarkan hasil perhitungan dengan menggunakan program statistik komputer SPSS for Windows diperoleh hasil sebagai berikut: 
Tabel 3.

Hasil Regresi Linier Berganda Mode Moderating Regression analysis

\begin{tabular}{|c|c|c|c|c|}
\hline Var & Koef & SE & t-test & Sig. \\
\hline $\mathbf{C}$ & 3,217 & 0,005 & 688,689 & 0,001 \\
\hline $\mathbf{X}_{1}$ & 0,001 & 0,000 & 7,787 & $\mathbf{0 , 0 8 1}$ \\
\hline $\mathbf{X}_{2}$ & 0,067 & 0,010 & 6,444 & 0,098 \\
\hline $\mathbf{X}_{\mathbf{3}}$ & 0,005 & 0,000 & 42,453 & $\mathbf{0 , 0 1 5}$ \\
\hline $\mathrm{X}_{1} * \mathrm{Z}_{1}$ & 0,002 & 0,000 & 74,797 & 0,009 \\
\hline $\mathbf{X}_{1} * \mathbf{Z}_{2}$ & 0,002 & 0,000 & 40,027 & $\mathbf{0 , 0 1 6}$ \\
\hline $\mathbf{X}_{2} * \mathbf{Z}_{1}$ & 0,030 & 0,001 & 50,267 & $\mathbf{0 , 0 1 3}$ \\
\hline $\mathbf{X}_{2} * \mathbf{Z}_{2}$ & 0,004 & 0,000 & 128,366 & $\mathbf{0 , 0 0 5}$ \\
\hline $\mathbf{X}_{3} * \mathbf{Z}_{1}$ & 0,005 & 0,000 & 58,624 & $\mathbf{0 , 0 1 1}$ \\
\hline $\mathbf{X}_{3} * \mathbf{Z}_{2}$ & 0,004 & 0,000 & 64,879 & $\mathbf{0 , 0 1 0}$ \\
\hline \multicolumn{5}{|l|}{$\mathbf{R}^{2}$} \\
\hline \multicolumn{5}{|l|}{ Adj. $\mathbf{R}^{2}$} \\
\hline \multicolumn{2}{|l|}{$\mathbf{F}$-statistik } & \multicolumn{3}{|c|}{$: 199,136$, Sig = 0,000. } \\
\hline \multicolumn{2}{|c|}{ DW-statistik } & \multicolumn{3}{|c|}{ : $\quad 2,368$} \\
\hline \multicolumn{5}{|c|}{$\begin{array}{ll}\mathbf{N} & : 11 \\
\end{array}$} \\
\hline
\end{tabular}

Sumber: Hasil Olah Data Regresi Linier Berganda, 2020.

Secara matematis hasil dari analisis regresi linier berganda model MRA tersebut dapat ditulis sebagai berikut:

$\mathrm{Y}=3,217+0,001 \mathrm{X}_{1}+0,067 \mathrm{X}_{2}+0,005 \mathrm{X}_{3}+0,002 \mathrm{X}_{1} * \mathrm{Z}_{1}+0,002 \mathrm{X}_{1} * \mathrm{Z}_{2}+$ $0,030 \mathrm{X}_{2} * \mathrm{Z}_{1}+0,004 \mathrm{X}_{2} * \mathrm{Z}_{2}+0,005 \mathrm{X}_{3} * \mathrm{Z}_{1}+0,004 \mathrm{X}_{3} * \mathrm{Z}_{2}$

\section{d. Uji Asumsi Klasik}

\section{Uji Normalitas}

Uji normalitas bertujuan untuk menguji apakah dalam model regresi variabel dependen dan variabel independen mempunyai distribusi normal atau tidak. Hasil uji normalitas dengan Kolmogorov Smirnov Test sebagai berikut:

\section{Tabel 4}

Hasil Uji Normalitas dengan Kolmogorov Smirnov Test

\begin{tabular}{cccc}
\hline Var & Sig. & DK & Keterangan \\
\hline Res1 & 0,949 & 0,05 & Normalitas \\
Res2 & 0,334 & 0,05 & Normalitas \\
\hline
\end{tabular}

Sumber: Hasil Uji Asumsi Klasik, 2020.

Berdasarkan hasil uji normalitas dengan Kolmogorov Smirnov Test di atas terlihat bahwa nilai probabilitas 0,949 dan $0,334>0,05$, maka model regresi memenuhi asumsi normalitas. 
2.

Uji Multikolinearitas

Uji Multikolinearitas adalah suatu keadaan dimana salah satu atau lebih variabel independen dapat dinyatakan sebagai kombinasi linier dari variabel independen lainnya. Hasil uji multikoliniearitas dengan metode VIF sebagai berikut:

Tabel 5

Hasil Uji Multikolinearitas dengan Metode VIF

\begin{tabular}{llll}
\hline Variabel & $\mathbf{V I F}$ & $\begin{array}{l}\mathbf{D} \\
\mathbf{K}\end{array}$ & Multikolinearitas \\
\hline $\mathbf{X}_{\mathbf{1}}$ & 1,011 & 10 & Tidak \\
$\mathbf{X}_{\mathbf{2}}$ & 1,134 & 10 & Tidak \\
$\mathbf{X}_{\mathbf{3}}$ & 1,128 & 10 & Tidak \\
$\mathbf{X}_{\mathbf{1}}$ & 5,890 & 10 & Tidak \\
$\mathbf{X}_{\mathbf{2}}$ & 5,970 & 10 & Tidak \\
$\mathbf{X}_{\mathbf{3}}$ & 5,779 & 10 & Tidak \\
$\mathbf{X} \mathbf{1} * \mathbf{Z 1}$ & 2,142 & 10 & Tidak \\
$\mathbf{X} \mathbf{1} * \mathbf{Z 2}$ & 2,133 & 10 & Tidak \\
$\mathbf{X 2} * \mathbf{Z 1}$ & 8,250 & 10 & Tidak \\
$\mathbf{X 2} * \mathbf{Z 2}$ & 2,950 & 10 & Tidak \\
$\mathbf{X 3} * \mathbf{Z 1}$ & 5,706 & 10 & Tidak \\
\hline
\end{tabular}

Sumber: Hasil Olah Data Regresi Linier Berganda, 2020.

Berdasarkan hasil uji multikolinearitas dengan metode VIF, nilai VIF $<10$, artinya bahwa semua variabel bebas tidak terjadi multikolinearitas, sehingga tidak membiaskan interprestasi hasil analisis regresi.

3. Autokorelasi

Pendeteksian asumsi autokorelasi dalam penelitian ini dilakukan dengan uji Durbin-Watson. Jika d-hitung < dL atau d-hitung > (4-dL), Ho ditolak, berarti ada autokorelasi. Jika dL $>$ d-hitung $<(4-\mathrm{dL})$, Ho diterima, berarti tidak terjadi autokorelasi . Jika dL < d-hitung < dU atau (4-dU) < d-hitung < (4-dL), maka tidak dapat disimpulkan ada tidaknya autokoelasi. Dari hasil regresi diperoleh nilai $\mathrm{D}-\mathrm{W}_{\text {statistik }}$ sebesar 2,141 dan 2,368. Dengan $\mathrm{n}=11, \mathrm{k}=3$, dan taraf nyata $(\alpha) 5 \%$, maka nilai $\mathrm{dL}=0,595, \mathrm{dU}=1,928$, sehingga $(4-\mathrm{dU})=4$ $1,928=2,072$ dan $(4-\mathrm{dL})=4-0,595=3,405$. Maka dari hasil diatas dapat disimpulkan bahwa tidak terjadi autokorelasi.

\section{Uji Heterokedastisitas}

Pendeteksian heteroskedastisitas dalam penelitian ini dilakukan dengan metode Glejser. Caranya dengan melihat nilai probabilitas $>0,05$, sehingga 
tidak terkena heteroskedastisitas. Hasil uji heteroskedastisitas dengan Glejser sebagai berikut:

Tabel 6

Hasil Uji Heteroskedastisitas dengan Glejser

\begin{tabular}{|c|c|c|c|}
\hline Var & Sig. & $\begin{array}{c}\text { Nilai } \\
\text { Kriti } \\
\text { S }\end{array}$ & Keterangan \\
\hline$\overline{X_{1}}$ & 0,735 & 0,05 & Homoskedastisitas \\
\hline $\mathbf{X}_{2}$ & 0,094 & 0,05 & Homoskedastisitas \\
\hline $\mathbf{X}_{3}$ & 0,962 & 0,05 & Homoskedastisitas \\
\hline $\mathbf{X}_{1}$ & 0,421 & 0,05 & Homoskedastisitas \\
\hline $\mathbf{X}_{2}$ & 0,722 & 0,05 & Homoskedastisitas \\
\hline $\mathbf{X}_{\mathbf{3}}$ & 0,636 & 0,05 & Homoskedastisitas \\
\hline $\begin{array}{l}\mathrm{X} 1 * \\
\mathrm{Z} 1\end{array}$ & 0,788 & 0,05 & Homoskedastisitas \\
\hline $\begin{array}{l}\mathrm{X} 1 * \\
\mathrm{Z} 2\end{array}$ & 0,586 & 0,05 & Homoskedastisitas \\
\hline $\begin{array}{l}\mathrm{X} 2 * \\
\mathrm{Z} 1\end{array}$ & 0,603 & 0,05 & Homoskedastisitas \\
\hline $\begin{array}{l}\mathrm{X} 2 * \\
\mathbf{Z 2}\end{array}$ & 0,458 & 0,05 & Homoskedastisitas \\
\hline $\begin{array}{l}\text { X3* } \\
\text { Z1 }\end{array}$ & 0,487 & 0,05 & Homoskedastisitas \\
\hline $\mathbf{X}_{2}$ & 0,673 & 0,05 & Homoskedastisitas \\
\hline
\end{tabular}

Sumber: Hasil Olah Data Regresi Linier Berganda, 2020.

Berdasarkan hasil uji heteroskedastisitas dengan menggunakan Glejser terlihat bahwa nilai probabilitas $>0,05$. Hal ini berarti model yang diestimasi bebas dari heteroskedastisitas.

\section{e. Uji Statistik}

\section{Uji t (t-test)}

Uji t digunakan untuk membuktikan pengaruh Return On Equity (X1), Rasio Operasi (X2), dan Cash Ratio (X3) terhadap Tingkat Kesehatan Keuangan (Y) dan apakah Penyertaan Modal memoderasi pengaruh Return On Equity, Rasio Operasi, dan Cash Ratio terhadap Tingkat Kesehatan Keuangan pada perusahaan PDAM Bantul dan apakah Efektivitas Penagihan memoderasi pengaruh Return On Equity, Rasio Operasi, dan Cash Ratio terhadap Tingkat Kesehatan Keuangan pada perusahaan PDAM Bantul secara individual (uji t) dengan asumsi bahwa variabel yang lain tetap atau konstan.

Berdasarkan hasil perhitungan dengan menggunakan program statistik komputer SPSS for Windows diperoleh hasil sebagai berikut: 
Tabel 7

\section{Hasil Uji t}

\begin{tabular}{lcc}
\hline Var & t-statistik & Sig. \\
\hline $\mathbf{X}_{\mathbf{1}}$ & 12,402 & $\mathbf{0 , 0 0 0}$ \\
$\mathbf{X}_{\mathbf{2}}$ & 4,707 & $\mathbf{0 , 0 0 2}$ \\
$\mathbf{X}_{\mathbf{3}}$ & 4,065 & $\mathbf{0 , 0 0 5}$ \\
$\mathbf{X}_{\mathbf{1}} * \mathbf{Z}_{\mathbf{1}}$ & 74,797 & $\mathbf{0 , 0 0 9}$ \\
$\mathbf{X}_{\mathbf{1}} * \mathbf{Z}_{\mathbf{2}}$ & 40,027 & $\mathbf{0 , 0 1 6}$ \\
$\mathbf{X}_{\mathbf{2}} * \mathbf{Z}_{\mathbf{1}}$ & 50,267 & $\mathbf{0 , 0 1 3}$ \\
$\mathbf{X}_{\mathbf{2}} * \mathbf{Z}_{\mathbf{2}}$ & 128,366 & $\mathbf{0 , 0 0 5}$ \\
$\mathbf{X}_{\mathbf{3}} * \mathbf{Z}_{\mathbf{1}}$ & 58,624 & $\mathbf{0 , 0 1 1}$ \\
\hline $\mathbf{X}_{\mathbf{3}} * \mathbf{Z}_{\mathbf{2}}$ & $\mathbf{6 4 , 8 7 9}$ & $\mathbf{0 , 0 1 0}$ \\
\hline
\end{tabular}

Sumber: Hasil Olah Data Regresi Linier Berganda, 2020.

Berdasarkan hasil olah data diatas dapat disimpulkan bahwa ada pengaruh positif dan signifikan untuk semua variabel prediktor terhadap Tingkat Kesehatan Keuangan (Y).

\section{Pengujian Goodness of Fit}

Hasil dari regresi linear berganda diperoleh $\mathrm{R}^{2}$ sebesar 0,885 , artinya variabel dependen (Y) dalam model yaitu Tingkat Kesehatan Keuangan (Y) dijelaskan oleh variabel independen yaitu Return On Equity (X1), Rasio Operasi (X2), dan Cash Ratio (X3) sebesar 88,5\%, sedangkan sisanya sebesar 11,5\% dijelaskan oleh faktor lain di luar model.

Hasil dari regresi linerar berganda model moderating regression analysis diperoleh $\mathrm{R}^{2}$ (Koefisien Determinasi) sebesar 0,900, artinya variabel dependen (Y) dalam model yaitu Tingkat Kesehatan Keuangan (Y) dijelaskan oleh variabel independen yaitu Return On Equity (X1), Rasio Operasi (X2), Cash Ratio (X3), Penyertaan Modal $\left(\mathrm{Z}_{1}\right)$, Efektivitas Penagihan $\left(\mathrm{Z}_{2}\right)$, Moderasi $\mathrm{X}_{1} * \mathrm{Z}_{1}$, Moderasi $\mathrm{X}_{1} * \mathrm{Z}_{2}$, Moderasi $\mathrm{X}_{2} * \mathrm{Z}_{1}$, Moderasi $\mathrm{X}_{2} * \mathrm{Z}_{2}$, Moderasi $\mathrm{X}_{3} * \mathrm{Z}_{1}$, dan Moderasi $\mathrm{X}_{3} * \mathrm{Z}_{2}$ sebesar $90,0 \%$, sedangkan sisanya sebesar $10,0 \%$ dijelaskan oleh faktor lain di luar model.

\section{KESIMPULAN}

- Hasil penelitian menunjukkan bahwa Return On Equity, rasio operasi, dan cash ratio berpengaruh positif dan signifikan terhadap Tingkat Kesehatan Keuangan pada perusahaan PDAM Bantul Tahun 2009-2019. Hal ini dapat diartikan, jika Return On Equity, rasio operasi, dan cash ratio mengalami peningkatan, maka Tingkat Kesehatan Keuangan pada perusahaan PDAM Bantul juga akan mengalami peningkatan.

- Hasil penelitian menunjukkan Penyertaan Modal memoderasi pengaruh Return On Equity, Rasio Operasi, dan Cash Ratio terhadap Tingkat Kesehatan Keuangan pada perusahaan 
PDAM Bantul Tahun 2009-2019. Hal ini berati, Penyertaan Modal dapat memperkuat pengaruh Return On Equity, Rasio Operasi, dan Cash Ratio terhadap Tingkat Kesehatan Keuangan pada perusahaan PDAM Bantul.

- Hasil penelitian menunjukkan Efektivitas Penagihan memoderasi pengaruh Return On Equity, Rasio Operasi, dan Cash Ratio terhadap Tingkat Kesehatan Keuangan pada perusahaan PDAM Bantul Tahun 2009-2019. Hal ini berati, Efektivitas Penagihan dapat memperkuat pengaruh Return On Equity, Rasio Operasi, dan Cash Ratio terhadap Tingkat Kesehatan Keuangan pada perusahaan PDAM Bantul.

\section{SARAN}

- Bagi perusahaan, Perusahaan PDAM Bantul dapat membuat isu positif yang membuat investor tertarik melakukan investasi dalam rangka meningkatkan modal perusahaan.

- Bagi investor, Tingkat kesehatan keuangan dapat dijadikan sebagai dasar pengambilan keputusan investasi karena aspek ini mengukur kemampuan perusahaan dalam menghasilkan tingkat laba atas investasi yang dilakukan pada perusahaan tersebut.

- Bagi peneliti lain, Peneliti lain dapat menambahkan variabel-variabel lain, misalnya modal, kekayaan yang diperkenankan, kewajiban, batas tingkat solvabilitas minimum yang dapat berdampak signifikan terhadap Tingkat Kesehatan Keuangan. 


\section{DAFTAR PUSTAKA}

Abraham, R., Harris, J., \& Auerbach, J. (2017). Earnings Yield as a Predictor of Return on Assets, Return on Equity, Economic Value Added and the Equity Multiplier. Modern Economy, 08(01), 10-24. https://doi.org/10.4236/me.2017.81002

Balfas, Hamud M. (2010). Hukum Pasar Modal Indonesia. Jakarta: Tatanusa.

Basu, S., \& Lokesh, K. S. (2014). Application of Multiple Linear Regression and Manova to Evaluate Health Impacts Due to Changing River Water Quality. Applied Mathematics, 05(05), 799-807. https://doi.org/10.4236/am.2014.55076

Brigham, E. F., \& Houston, J. F. (2010). Manajemen Keuangan Edisi Kedelapan. In Erlangga Jakarta. https://doi.org/10.1016/0377-841X(78)90069-4

BPKP DIY. (2019). Laporan Evaluasi Kinerja Perusahaan Daerah Air Minum (PDAM) Kabupaten Bantul Tahun Buku 2018. Yogyakarta: BPKP Provinsi DIY.

Darmadji, T., \& Fakhruddin, H. M. (2012). Pasar Modal Di Indonesia. In Salemba Empat.

Dendawijaya. (2009). Manajemen Perbankan. Edisi Revisi Sembilan. https://doi.org/10.1007/s00262-007-0394-0

Ghozali, I. (2016). Ghozali, Imam. (2016). Aplikasi Analisis Multivariate dengan Program IBM SPSS 23. Semarang: BPFE Universitas Diponegoro. IOSR Journal of Economics and Finance. https://doi.org/https://doi.org/10.3929/ethz-b-000238666

Gujarati, D. N., \& Porter, D. C. (2011). Econometria Básica. In Basic Econometrics. https://doi.org/10.1126/science.1186874

Harahap, S. S. (2007). Analisis Krirtis Atas Laporan Keuangan. Jakarta: PT.Raja Grasindo Persada.

Mahmudi Pdf Download Akuntansi Sektor Publik Mahmudi Pdf Download 1 / 3. Akuntansi Sektor Publik, 351-354.

Santoso, Budi. (2010). Profit Berlipat dengan Investasi Tanah dan Rumah. Jakarta: Elex Media Komputindo. 
124 | Bisman: Volume 3. Nomor 2, Agustus 2020.

Yuwono, Sony. (2010). Petunjuk Praktis Penyusunan Balanced Scorecard: Menuju Organisasi yang Berfokus pada Strategi. Jakarta: Gramedia Pustaka Utama. 